\title{
A review of the activation triggers and reasons for stand downs of a Helicopter Emergency Medical Service (HEMS)
}

\author{
Elizabeth G Evans ${ }^{1 *}$, Anthony Hudson ${ }^{1}$, Emily McWhirter ${ }^{2}$, Richard Lyon ${ }^{2}$ \\ From London Trauma Conference 2013 \\ London, UK. 10-13 December 2013
}

\section{Background}

HEMS crews - a pilot, doctor and paramedic - provide advanced pre-hospital care to acutely ill or injured patients. Sometimes HEMS is deployed only to be no longer required; a stand down. This means a vital resource is unavailable whilst costing the charity money and requiring crews to take unnecessary risks.

\section{Method}

Data was collected from the KSSAAT database - HEMSbase. For each stand down job (June 2013 - August 2013) the mechanisms of injury, reasons for stand downs, times of stand downs and call dispatch types were noted. Monthly summary data sheets were then used to compare this data to that of successful jobs.

\section{Results}

Of the 561 jobs HEMS was deployed on in this time period, 226 (38\%) were stand downs. All mechanisms of injury has a $>25 \%$ stand down rate with assault jobs having the most (57\%). 34\% of stand downs were due to major injuries turning out to be minor although $20 \%$ of jobs did not have documented reasons. Interestingly, only $10 \%$ of stand downs were due to technical issues such as weather, re-tasking (sent to another job) or delays en route. In total, $61 \%$ of stand downs were immediate dispatches (HEMS is deployed on initial information received) compared to the $30 \%$ that were sent after interrogation (more information is gathered). Most stand downs occurred at night (19:01 07:00) and there were peaks at paramedic shift change overs (07:00 - 19:00).

\section{Conclusion}

Improving the quality of initial information could improve tasking accuracy and hence reduce stand downs. The improvements are two-fold with more tasking training for staff and development of the dispatch criteria.

\section{Authors' details}

${ }^{1}$ St George's University of London, UK. ${ }^{2}$ Kent, Surrey, Sussex Ambulance Trust (KSSAAT) - Helicopter Emergency Medical Service, UK.

Published: 7 July 2014

\section{References}

1. Kent, Surrey and Sussex Air Ambulance Trust: What we do., [ONLINE] Available at http://www.kssairambulance.org.uk/About/what_we_do. [Accessed 04 October 13].

2. Giannakopoulos $\mathrm{G}$, et al: Criteria for cancelling helicopter emergency medical services (HEMS) dispatches. Emergency Medicine Journal 2011, 24(7).

doi:10.1186/1757-7241-22-S1-P5

Cite this article as: Evans et al:: A review of the activation triggers and reasons for stand downs of a Helicopter Emergency Medical Service (HEMS). Scandinavian Journal of Trauma, Resuscitation and Emergency Medicine 2014 22(Suppl 1):P5.

Submit your next manuscript to BioMed Central and take full advantage of:

- Convenient online submission

- Thorough peer review

- No space constraints or color figure charges

- Immediate publication on acceptance

- Inclusion in PubMed, CAS, Scopus and Google Scholar

- Research which is freely available for redistribution 